\title{
Influence of Employee Competence and Work Environment on The Quality of Fire Management Services With AHP Method
}

\author{
Dewi Laraswati1, Marlina2,Indarti3 \\ ${ }^{1}$,Computer Technology, Bina Sarana Informatika University \\ 2,3 Information Systems, Bina Sarana Informatika University
}

\begin{tabular}{l} 
Article Info \\
Article history: \\
Received 1125,2021 \\
Revised 12 15, 2021 \\
Accepted 12 21, 2021 \\
\hline
\end{tabular}

Keywords:

AHP

Method

Competence

Official

Fire

\begin{abstract}
The purpose of this study is to find out the influence of employee competence and the work environment on the quality of fire management services in the South Jakarta Administrative City Fire and Rescue Service Tribe. The method used is a quantitative method through the dissemination of questionnaires, with a population of 473 people or respondents and the sample is 83 people using SPSS Version 23 for windows with the aim to facilitate and ensure the calculation and processing of data has been done correctly.
\end{abstract}

This is an open access article under the CC BY-SA license.

\author{
Corresponding Author: \\ Indarti \\ Information Systems, \\ Bina Sarana Informatika University \\ Central Jakarta \\ Email: indarti.ini@bsi.ac.id \\ (c) The Author(s) 2021
}

\section{Introduction}

The South Jakarta Administrative City Fire and Rescue Service tribe must have a high attitude and interest in the task for which it is responsible, have a strong commitment to work as well as possible, by providing the best quality of service to strive to improve the quality of self or competence in facing every challenge that exists. The quality of service provided is expected to be able to meet the wishes of the community.

In accordance with the Decree of the Governor of the Special Regional Province of the Capital City of Jakarta Number 264 of 2016 [1], on the organization and working arrangements of the DKI Jakarta Provincial Fire and Rescue Service.To carry out this task, the Fire and Rescue Service Tribe must be supported by good staffing arrangements in providing services to the community to adequate fire disaster prevention and management. Amir (2015:5)[2] states that performance is something displayed by a person or a process related to a assigned work task. Optimal service certainly continues to be pursued and becomes a strong commitment in order to achieve the mission vision of the Fire and Rescue Service of the South Jakarta AdministrativeCity. Here are some research literature related to research problems as follows:

Evi Wulandari (2018)[3] with the title: "Effect of Occupational Discipline and Occupational Health Safety on Employee Performance". The purpose of this writing is to find out how much influence the motivation of work and competence of civil servants on the quality of service in the State Staffing Agency. The method used in 
this study is a quantitative method through surveys, with a population of 447 people so that the calculation of samples using using multiple linear regressions.

Anton Risparyanto (2017)[4] with judul: the influence of motivation and competence on the quality of librarian services in the directorate of library of. Islamic universities indonesia. This research aims to find out the influense motivation and competence to the quality of service of library officers only (partial)1 and together. Lailatul Badriah (2017)[5] with the title of the influence of competence and motivation on the performance of employees of the savings and loan cooperative (KSP) main work of the Semarang branch. This research is a descriptive analysis with the results of research that shows that there is an influence of competence and motivation on the performance of Luthfiana Nurul Wakhidah, Hengky Pramusinto [6] with the title Of Influence of Competence, Employee Discipline, and Physical Work Environment on The Quality of Employee Service. Research is quantitative research using survey methods.

\section{Research Method}

Research methods are scientific ways to obtain valid data with the aim of discovering, developing, and proving, a particular knowledge so that in turn it can be used to understand, solve, and anticipate problems in the business field. ].

\section{a. Koseptual Skeleton}

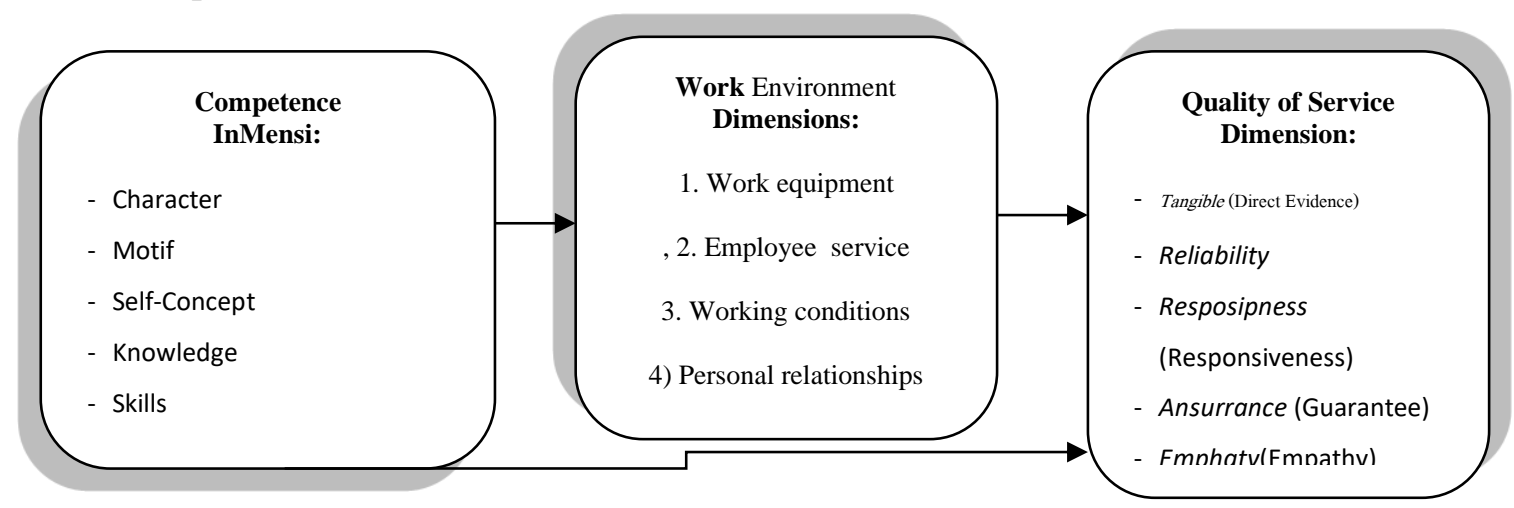

Figure 1. Framework of Thought

The research design used is descriptive research with a qualitative approach implemented at the Fire and Rescue Service of the Administrative City of South Jakarta. The population in this study, namely the people in the Administrative City of South Jakarta amounted to 473 respondents. The sample was only 83 respondents or employees. Population [9] is a generalization region consisting of objects or subjects that have a certain quantity and characteristics set by the researcher to be studied and then drawn conclusions.

a. Variable Grid

The grid of research variables contains a description of dimensions (subvariable), each dimension formulated its indicator to then become a questionnaire item or questionnaire. The following is presented in the instrument grid of each research variable as follows:

Table 2. Competency Variable Research Instrument Grid

\begin{tabular}{|c|c|c|c|}
\hline Variable & Dimension & Indicators & $\begin{array}{c}\text { Statement } \\
\text { Item }\end{array}$ \\
\hline \multirow[t]{5}{*}{$\begin{array}{l}\text { Competence } \\
\text { (X1) }\end{array}$} & 1. Character & $\begin{array}{l}\text { a. Mental training of employees } \\
\text { b. Formation of employee characteristics } \\
\text { c. Forming the personality of the officer }\end{array}$ & $\begin{array}{l}1 \\
2 \\
3\end{array}$ \\
\hline & 2. Motive & $\begin{array}{l}\text { a. Encourage employees to realize work goals } \\
\text { b. Meet your wants and needs } \\
\text { c. Encourage you to work harder }\end{array}$ & $\begin{array}{l}4 \\
5 \\
6\end{array}$ \\
\hline & 3. $\quad$ Self-Concept & $\begin{array}{l}\text { a. The confidence that individual employees have } \\
\text { b. Physical self-image is related to appearance. }\end{array}$ & $\begin{array}{l}7 \\
8\end{array}$ \\
\hline & 4. Knowledge & $\begin{array}{l}\text { a. Have knowledge that can be useful in the scope of } \\
\text { work } \\
\text { b. Understanding the work done }\end{array}$ & $\begin{array}{c}9 \\
10\end{array}$ \\
\hline & 5. Skills & $\begin{array}{l}\text { a. Ability to use work equipment } \\
\text { b. Mastering the expertise of a particular field }\end{array}$ & $\begin{array}{l}11 \\
12\end{array}$ \\
\hline
\end{tabular}


Table 3. Working Environment Research Variable Instrument Grid

\begin{tabular}{|c|c|c|c|}
\hline Variable & Dimension & Indicators & $\begin{array}{c}\text { Items } \\
\text { Statement }\end{array}$ \\
\hline \multirow[t]{5}{*}{$\begin{array}{l}\text { Work Environment } \\
\text { (X2) }\end{array}$} & 1. Division of Labor & $\begin{array}{l}\text { a. As per Jobdesk } \\
\text { b. Know the task } \\
\text { trees and functions }\end{array}$ & $\begin{array}{l}1 \\
2\end{array}$ \\
\hline & 2. Responsibility & $\begin{array}{l}\text { a. Understand Basic Tasks and Functions } \\
\text { b. Initiative Attitude }\end{array}$ & $\begin{array}{l}3 \\
4\end{array}$ \\
\hline & 3. Task Mechanism & $\begin{array}{l}\text { a. According to SOP } \\
\text { b. Follow orders } \\
\text { Superior }\end{array}$ & $\begin{array}{l}5 \\
6\end{array}$ \\
\hline & 4. Consult with Superiors & $\begin{array}{l}\text { a. Taking Action } \\
\text { b. Decision }\end{array}$ & $\begin{array}{l}7 \\
8\end{array}$ \\
\hline & 5. Leaders' Relationships & $\begin{array}{l}\text { a. Good cooperation in all fields } \\
\text { b. Follow the leader's orders }\end{array}$ & $\begin{array}{c}9 \\
10\end{array}$ \\
\hline
\end{tabular}

Table 4. Service Quality Variable Research Instrument Grid

\begin{tabular}{|c|c|c|c|}
\hline Variable & Dimension & Indicators & $\begin{array}{c}\text { Items } \\
\text { Statement }\end{array}$ \\
\hline \multirow[t]{5}{*}{$\begin{array}{c}\text { Quality of } \\
\text { Service } \\
\text { (Y) }\end{array}$} & 1. Tangible (Direct Evidence), & $\begin{array}{l}\text { c. There is a building in providing a form of } \\
\text { service. } \\
\text { d. Pincompleteness and equipment used } \\
\text { (technology) } \\
\text { e. Good employee appearance }\end{array}$ & $\begin{array}{l}1 \\
2 \\
3\end{array}$ \\
\hline & 2. Reliability & $\begin{array}{l}\text { c. Performance must be in line with customer } \\
\text { expectations which means punctuality } \\
\text { d. Thesame for all customers without errors } \\
\text { e. Sympathetic attitude with high work } \\
\text { accuracy }\end{array}$ & $\begin{array}{l}4 \\
5 \\
6\end{array}$ \\
\hline & f. $\quad$ Resposipness (Responsiveness) & $\begin{array}{ll}\text { c. } & \text { Service quickly and precisely } \\
\text { d. } & \text { Clear delivery of information }\end{array}$ & $\begin{array}{l}7 \\
8\end{array}$ \\
\hline & 4. Ansurrance (Guarantee) & $\begin{array}{ll}\text { c. } & \text { Growing customer trust } \\
\text { d. } & \text { Provide a sense of security to customers }\end{array}$ & $\begin{array}{c}9 \\
10\end{array}$ \\
\hline & 5. Emphaty(Empathy) & $\begin{array}{l}\text { c. Providing sincere service } \\
\text { d. Understand customer needs }\end{array}$ & $\begin{array}{l}11 \\
12\end{array}$ \\
\hline
\end{tabular}

\section{Result and Discussion}

A. Data Quality Test Results

a. Research Scale Item Item Validity Test

Table 5 Results of Calculation of Employee Competency Scale Validity Test (X1)

\begin{tabular}{|c|c|c|c|}
\hline Question & Rhitung value & Rtabel value & Criterion \\
\hline KTP1 & 0,595 & 0,361 & Valid \\
\hline KTP2 & 0,505 & 0,361 & Valid \\
\hline KTP3 & 0,703 & 0,361 & Valid \\
\hline PB1 & 0,615 & 0,361 & Valid \\
\hline TP2 & 0,568 & 0,361 & Valid \\
\hline TP3 & 0,531 & 0,361 & Valid \\
\hline BJ1 & 0,680 & 0,361 & Valid \\
\hline BJ2 & 0,608 & 0,361 & Valid \\
\hline PBA1 & 0,527 & 0,361 & Valid \\
\hline PBA2 & 0,609 & 0,361 & Valid \\
\hline PB3 & 0,566 & 0,361 & Valid \\
\hline PM1 & 0,464 & 0,361 & Valid \\
\hline
\end{tabular}




\begin{tabular}{|c|c|c|c|}
\hline PM2 & 0,590 & 0,361 & Valid \\
\hline PM3 & 0,632 & 0,361 & Valid \\
\hline SH1 & 0,746 & 0,361 & Valid \\
\hline SH2 & 0,621 & 0,361 & Valid \\
\hline SH3 & 0,558 & 0,361 & Valid \\
\hline ST1 & 0,671 & 0,361 & Valid \\
\hline ST2 & 0,769 & 0,361 & Valid \\
\hline HK1 & 0,545 & 0,361 & Valid \\
\hline
\end{tabular}

Based on the employee competency variables shown by the table above, it can be seen that employee competency variables are declared valid for all statement items. After an invalid statement is issued. 2). Validity of Work Environment Scale Item Items (X2)

Table 6. Results of Calculation of Working Environment Scale Validity Test (X2)

\begin{tabular}{|c|c|c|c|}
\hline Question & Ter rhitung value & Rtabel value & Criterion \\
\hline TK1 & 0,768 & 0,361 & Valid \\
\hline TK2 & 0,659 & 0,361 & Valid \\
\hline RK1 & 0,628 & 0,361 & Valid \\
\hline PP1 & 0,594 & 0,361 & Valid \\
\hline TF1 & 0,645 & 0,361 & Valid \\
\hline TF2 & 0,510 & 0,361 & Valid \\
\hline KF1 & 0,799 & 0,361 & Valid \\
\hline KF2 & 0,854 & 0,361 & Valid \\
\hline KF3 & 0,757 & 0,361 & Valid \\
\hline KF4 & 0,681 & 0,361 & Valid \\
\hline KF5 & 0,550 & 0,361 & Valid \\
\hline
\end{tabular}

Based on table 9 above, it was concluded that from 12 items of question items in the trial 30 respondents to the working environment variable $(\mathrm{X} 2)$. this indicates that all item items of the question are valid, this is because all r-calculated values of the Work Environment $(\mathrm{X} 2)>$ r-table $(0.361)$ at a significant level of $5 \%$.

3). Validity of Item Item Service Quality Scale (Y)

Using the critical number correlation $\mathrm{r}$-calculated $95 \%$ or with $\alpha=0.05$ and rtabel value of 0.361 (rtabel= $\mathrm{n}=30$ ), it can be obtained the results of the validity of the item of a research instrument. If the rhitung > rtabel, then the item of the question item is declared valid and vice versa if the rhitung < rtabel, then the item of the question item is declared invalid. Based on table IV.10 above obtained the conclusion that from 9 items of question items in the trial 30 respondents on the Competency variable (Y). indicates that all item items of the question are valid. This is because all r-calculated Service Quality (Y) values > r-table $(0.361)$ at a significant level of $5 \%$.

\section{A. Research Scale Construct Reliability Testing}

Reliability testing in this study is used to show the level of reliability consistency of a construct of questions used. Reliability tests can only be performed after an instrument has been confirmed to be valid. Calculations testing the reliability of this research instrument use the formula of the Alpha Cronbach method. To see the reliability of the construct the question is to measure the Cronbach' Alpha coefficient with the help of the SPSS 23 program. Alpha values vary from 0 to 1 , a question can be categorized as reliable if the alpha value is greater than 0.700 .

1). Employee Competency Reliability Test (X1) 
Table 7. Calculation of Reliability of Employee Competency Construct (X1) Reliability Statistics

\begin{tabular}{|l|l|}
\hline Cronbach'c Alpha & N of Items \\
\hline .904 & 20 \\
\hline
\end{tabular}

Based on the data in table 10 above cronbach's Alpha value the employee competency variable (X1) is 0.904 . Since the employee competency variable (X1) has a Cronbach Alpha value of 0.904 greater than 0.700 , it can be concluded that the construct of questions from the employee competency variable (X1) is reliable.

2). Work Environment Reliability Test (X2)

Table 8. Calculation of Reliability of Work Environment Construct (X2) Reliability Statistics

\begin{tabular}{|ll|l|}
\hline Cronbach'c Alpha & N of Items \\
\hline & .888 & \\
\hline
\end{tabular}

Based on the data in table 11 above cronbach's Alpha value the Working Environment variable (X2) is 0.888. Since the work environment (X2) has a Cronbach Alpha value of 0.888 greater than 0.700 , it can be dreamed up that the construct question from the SSP and nai is reliable.

3). Service Quality Reliability Test (Y)

Table 9. Calculation of Reliability of Service Quality Construct (Y) Reliability Statistics

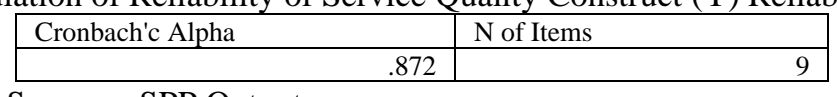

Source: SPP Output

Based on the data in table 12 above the value of Cronbach's Alpha Service Quality variable (Y) is 0.872 . Since the Service Quality variable (Y) has a Cronbach Alpha value of 0.872 greater than 0.700 , it can be concluded that the question construct of the Service Quality variable (Y) is reliable.

Table 10. Summary of Employee Competency Construct Reliability (X1), Work Environment (X2), Service Quality (Y)

\begin{tabular}{|c|l|c|c|c|}
\hline No. & Variable & Cronbach Alpha Value & Standard Value & Information \\
\hline 1 & Employee Competence & 0,904 & 0,700 & Reliable \\
\hline 2 & Work Environment & 0,888 & 0,700 & Reliable \\
\hline 3 & Employee Quality & 0,872 & 0,700 & Reliable \\
\hline
\end{tabular}

Based on data in table 13 above Cronbach's Alpha values of employee competency variables (X1), Work Environment (X2), and Service Quality (Y) are 0.904, 0.888, and 0.872. This suggests that all research instruments are declared reliable because all instruments have an alpha cronbach value of more than 0.700. Since all questions are reliable, in conclusion this research instrument can be used several times to measure the same object and will produce the same data (consistent). ).

B. Multiple Regression Test

1. The coefficient of determination is a coefficient that shows the magnitude of variation caused by the predictor or the magnitude of the contribution (influence) given by the independent variables against dependent variables expressed by percentages. Age coefficient of determination between computer variables want wrong canoework (X1), and work environment (X2), to quality of service (Y). Predictors:(Constant), Work Environment (X2), Employee competence (X1)b. Dependent Variables: Quality of Service (Y) Source Output :SPSS 23, Based on table 4.23 summary model obtained coefficient value of determination (R2) variable Employee competence (X1), Work Environment (X2), To the Quality of Service (Y) is 0.397 (39.7\%), meaning that the contribution of employee competency variables (X1), and work environment (X2), to quality of service (Y) is as large as $39.7 \%$ and the remaining $60.7 \%(100 \%-39.7 \%=60.7 \%)$ came from variables or other factors that have not been studied in the study, such as salary,intensive, training, and Others.

2. The T-test aims to determine the magnitude of the influence of each independent variable, namely employee competency variables (X1), and work environment (X2), on quality of service (Y). The T test was used to test the H1 hypothesis, comparing Thitung to Ttabel. Where the T-table is calculated 
with the formula $\mathrm{df}=\mathrm{n}-\mathrm{k}, \mathrm{k}$ is the number of independent variables. If Thitung is greater than Ttabel and a significant value smaller than $\alpha=0.05$, then H1diterima and Ho are rejected and vice versa If Thitung is smaller than Ttabel and significant value Greater than $\alpha=0.05$ then H1ditolak and Ho are accepted.

3. Employee competence (X1) partially affects the quality of service (Y). The value of t- calculated employee competency variable $(\mathrm{X} 1)$ is $3,968>$ the value t-table $1.67(\mathrm{n}-\mathrm{k}=83-2=81)$ and the significant value is $0.000<\alpha=0.05$. Because the value of t-calculated employee competence (X1) which is $3,968>$ the value of t-table $=1.67$ and a significant value of $0.000<\alpha=0.05$, then Ho was rejected and H1diterima. This means that the employee competency variable (X1)has a significant and positive effect on service quality (Y). This is in line with the research conducted by this study in line with research conducted by Irawati and Ezra with the influence of employee competence and organizational culture. on the performance of production operators in PT.xxx who say that a significant value of $0.000<\alpha=0.05$ then $\mathrm{H} 1$ is accepted which means that there is an influence between the influences competence of employees to performance.

4. The Work Environment (X2) partially affects performance

Employee (Y). The t-count value of the Occupational Safety and Health (X2) variable is $2.395>$ slai $t$ table $1.67(n-k=83-2=81)$ and the significant value is $0.019<\alpha=0.05$. Because the Occupational Safety and Health (X2) t-count value is 2,395> the value of t-table $=1.67$ and the significant value of $0.019<\alpha=$ 0.05, Then Ho was rejected and Ha2diterima. This means that the Occupational Safety and Health (X2) variable has a significant and positive effect on The Quality of Service (Y). this is in line with research conducted by Muhammad (2017) entitled the effect of occupational safety health on quality of service in PT. State lisrik company (PLN) suluttenggo palu area. That said, a significant value of $0.000<\alpha=0.05$ then there is a significant influence between the health variables of safety and performance. And the significance value of $0.000<\alpha=0.05$ then there is an effect on work safety on performance. This is also in line with research according to Purnamasari (2017) which shows that the value of $t$ calculated $(5,621)$ $>\mathrm{t}$ table $(1,670)$ then $\mathrm{H} 1$ is accepted meaning that there is an influence between occupational health and safety affects performance. Based on Table 4.24 The above can be made regression equation as follows: $\mathrm{Y}=\mathrm{a}+\mathrm{b} 1 \mathrm{X} 1+\mathrm{b} 2 \mathrm{X} 2+\varepsilon \mathrm{Y}=13,309+0.207 \mathrm{X} 1+0.1897 \mathrm{X} 2+\varepsilon$ at the time of the employee Competency variable (X1), and Occupational Safety and Health (X2) is of constant value, then the Service Quality value (Y) is 13,309. The magnitude of the influence on the employee competency variable (X1) on service quality (Y) is 0.207 and positively affects, where the increase in employee competence (X1) by one unit will affect the increase in service quality (Y) by 0.207 (20.7\%). The amount of influence on the working environment variable (X2) on service quality (Y) is 0.987 and positively affects, where the improvement of the work environment (X2) by one unit will affect the increase in service quality (Y) by $0.189(18.9 \%)$. Based on the discussion of the test above, it can be concluded that it is the employee competency variable (X1) that most dominantly affects the Service Quality variable (Y) which is 3,968, then the Work Environment variable (X2) to Service Quality (Y) with the magnitude of the influence is 2,395.3). The Ftest aims to determine the influence jointly between independent variables, namely competency variables (X1), and work environments (X2), on service quality (Y). This test was used to prove the Ha3 hypothesis. By comparing the value of F-calculate with the value of F-table. The F-table is calculated with the formula df $1=\mathrm{k}-1, \mathrm{df} 2=\mathrm{n}-\mathrm{k}, \mathrm{k}$. The results of the F statistical test can be seen in the table below, if Fhitung $>$ Ftabel and a significant value smaller than $\alpha=0.05$ then Haditerima and reject H0, while if Fhitung < Ftabek and significant value greater than $\alpha=0.05$ then H0diterima and reject Ha.

\section{Hypotheses in research: \\ Hypothesis 3}

Hypothesis 3H03: competence (X1), and work environment (X2) simultaneously have no effect on service quality (Y).

Ha3 competencies (X1), and Work environment (X2) simultaneously

Quality of service (Y). Ha3. F-table calculated with the formula df1 =k-1, df2=n-k, $\mathrm{k}$ is the number of competency variables (X1), and the Work environment (X2) to service quality (Y). Based on the Anova table above shows that the value of F-calculated at 26,296> F-table of 3.12 (df1 $=3-1=2$, df $2=83-3=$ 80 ) with a significant value of $0.000<\alpha=0.05$. Since F-calculates $26,296>$ F-table 3.12 and a significant value of $0.000<\alpha=0.05$, then $\mathrm{H} 0$ is rejected and H1diterima, This proves that the variable competence (X1), and the Work environment (X2) are independently Simultaneously has a significant and positive effect on the quality of service (Y).

This is in line with research conducted by Muhammad (2017) entitled the effect of occupational safety health on the Quality of Service at PT. State lisrik company (PLN) suluttenggo palu area. That 
said that a significant value of $0.000<\alpha=0.05$ then there is a significant influence between competency variables on service quality. And the significance value of $0.000<\alpha=0.05$ then there is an effect on the work environment on the quality of service. This is also in line with research according to Purnamasari (2017) which shows that the value of $t$ calculated $(5,621)>t$ table $(1,670)$ then $\mathrm{H} 1$ is accepted meaning that there is an influence between competence and The work environment affects the quality of service and fire management.

1. Descriptive Data of Respondent Characteristic Frequency

In this study, the number of respondents who were the subject of the study was 83 employees in the South Jakarta Administrative City Fire and Rescue Service Tribe. Before analyzing further data, a picture of the characteristics of respondents will first be presented as to the gender, age, working period, education, departments, and groups. For more details, you can see it at the following table.

1. Descriptive Data of Respondent Frequency By Gender

Table 11. Descriptive of Respondents' Frequency By Gender

\begin{tabular}{|l|l|l|}
\hline Gender & Frequency & Percentage $(\%)$ \\
\hline Man & 83 & 100 \\
\hline Woman & 0 & 0 \\
\hline Sum & 83 & 100 \\
\hline
\end{tabular}

From table 11 descriptive frequency of respondents based on gender of 83 respondents studied showed that the frequency of employees of the South Jakarta Fire Management Service tribe was dominated by men. That's 83 people (100\%). So based on the table above it can be concluded that the number of employees is all men versus female employees. This is very appropriate, because in the South Jakarta Fire Management Service Tribe the type of work carried out is very heavy work that requires a strong physical and mental. Such as providing water, driving a car quickly, spraying water up to a certain height, and evacuating the victims.

\section{Descriptive Data of Respondent Frequency By Age}

Table 12. Descriptive of Respondents' Frequency By Age

\begin{tabular}{|c|c|c|}
\hline Age & Frequency & Percentage (\%) \\
\hline$<36$ years old & 11 & 13.25 \\
\hline $36-44$ years & 42 & 50.60 \\
\hline $45-49$ years & 14 & 16.87 \\
\hline $50-56$ years old & 16 & 19.28 \\
\hline Sum & 83 & 100 \\
\hline
\end{tabular}

From table 12 above it can be known that most respondents are dominated by the number of frequencies of employees who have a lifespan of less than 36 which amounted to 11 people $(13.25 \%)$, the number of frequencies Employees who have a lifespan of 36 to 44 years, which amount to 42 people $(50.60 \%)$, the number of employees who have a age of 45 to 49 years is 14 people (16.87\%), and the number of employees who have a age of 45 to 49 years is 14 people (16.87\%), and the number of employees who have a age of 45 to 49 years is 14 people $(16.87 \%$ ), and the number of employees who have a age of 45 to 49 years is 14 people (16.87\%), and the number of employees who have a age of 45 to 49 years is 14 people ( The frequency of employees who have a lifespan of 50 to 56 years is 16 people (19.28\%). When viewed from the age level of employees of the South Jakarta Fire Management Agency tribe is quite good, because as many as 42 people $(50.60 \%)$ are employees who have a strong and mature mental physical. to work and face all dangers in the field

3. Descriptive Data of Respondent Frequency By Department

Table 13. Descriptive of Respondent Frequency By Department

\begin{tabular}{|c|c|c|}
\hline Position & Number of respondents & Percentage (\%) \\
\hline Squad Commander & 10 & 12.05 \\
\hline Squad Chief & 22 & 26.51 \\
\hline Member & 43 & 51.81 \\
\hline Expert Operational Staff & 8 & 9.64 \\
\hline Sum & 83 & 100 \\
\hline
\end{tabular}

Based on table 13 descriptive frequency of respondents based on the position of 83 respondents studied showed that the number of frequency of employee respondents in the South Jakarta Fire Management Agency tribe is the most Many are positions as fire department members, namely as many

Jurnal Teknologi Dan Open SourceVol. 4, No. 2, December 2021: 270 - 279 
as 43 people $(51.81 \%)$, then the number of frequency of employee respondents in the South Jakarta Fire Management Service Tribe with positions as the head of the squad, which is as many as 22 people (26.51\%), the number of employee respondents in the South Jakarta Fire Management Service Tribe with the position of commander-in-chief is as many as 10 people $(12.05 \%)$, and the number of The frequency of employee respondents in the South Jakarta Fire Management Service Tribe with positions as expert operational staff is as many as 8 people $(9.64 \%)$.

4. Descriptive Data of Respondent Frequency By Group

Table 14. Descriptive frequency of respondents by
\begin{tabular}{|c|c|c|}
\hline Group & Number of respondents & Percentage (\%) \\
\hline 1C & 0 & 0.00 \\
\hline 1D & 2 & 2.41 \\
\hline 2A & 6 & 7.23 \\
\hline 2B & 11 & 13.25 \\
\hline 2C & 15 & 18.07 \\
\hline 2D & 20 & 24.10 \\
\hline 3A & 10 & 12.05 \\
\hline $3 \mathrm{~B}$ & 8 & 9.64 \\
\hline 3C & 5 & 6.02 \\
\hline 3D & 4 & 4.82 \\
\hline 4A & 2 & 2.41 \\
\hline 4B & 0 & 0.00 \\
\hline Sum & 83 & 100 \\
\hline
\end{tabular}

Based on a table of 20 descriptive frequency of respondents based on the group of 83 respondents studied showed that the number of employee respondents in the South Jakarta Fire Management Agency tribe was the most Many are Group 1D which is as many as 2 people $(2.41 \%)$, then the number of staff respondents in the South Jakarta Fire Management Agency Tribe with group 2A is as many as 6 people $(7.23 \%)$, Furthermore, group 2B number of frequencies as many as 11 people $(13.25 \%)$, the number of frequency of employee respondents in the South Jakarta Fire Department tribe with group $2 \mathrm{C}$ is as many as 15 people $(18.07 \%)$, then group 2D number of ferkuensinya as many as 20 people $(24.10 \%)$, the number of frequency of employee respondents in the South Jakarta Fire Service Tribe group 3A as many as 10 people $(12.05 \%)$, then the number of frequencies group 3B in the South Jakarta Fire Service Tribe as many as 8 people $(9.64 \%)$, then the number of frequency of group 3C in the South Jakarta Fire Service Tribe as many as 5 people $(6.02 \%)$, the number of frequency of group 3D in the South Jakarta Fire Department Tribe as many as 4 people $(4.82 \%)$, then then the frequency of group 4A in the South Jakarta Fire Service Tribe as many as 2 people $(2.41 \%)$

5. Descriptive Data of Respondent Frequency Based on Working Period

Table 15. Descriptive of Respondent Frequency Based on Working Period

\begin{tabular}{|c|c|c|}
\hline Working Time & Number of respondents & Percentage (\%) \\
\hline 1 - 5 Years & 12 & 14,46 \\
\hline 6 - 10 years & 16 & 19,28 \\
\hline 11 - 20 years & 27 & 32,53 \\
\hline 21 -25 Years & 17 & 20,48 \\
\hline 26 - 30 years & 11 & 13,25 \\
\hline Sum & 83 & 100 \\
\hline
\end{tabular}

Based on a table of 15 descriptive of the frequency of respondents based on the working period of 83 respondents studied showed that the most number of employee frequencies were employees whose working life was between 11 - 20 years, which is 27 people $(32.53 \%)$, then the number of frequencies of employees whose working life was between 17 people $(20.48 \%)$, the number of frequency of employees whose working life was between 6 - 10 years, which was 16 people (19.28\%), The number of employees whose working life is between 1 - 5 years is as many as 12 people (14.46\%), and the number of frequencies of employees whose working life is between 26 - 30 years is as many as 11 people $(13.25 \%)$. When viewed from the working period of employees of the Fire and Rescue Service of the City of South Jakarta Administration is very good, because as many as 27 people (32.53\%) and 17 people (20.48\%) are employees who have very long work experience so they are very experienced in working and easy to solve problems every time facing all 
problems in the field.

6. Descriptive Data of Respondent Frequency Based on Education

Table 16. Descriptive of Respondents' Frequency Based on Education

\begin{tabular}{|c|c|c|}
\hline Education & Number of respondents & Percentage (\%) \\
\hline JUNIOR & 3 & 3.61 \\
\hline SMA & 10 & 12.05 \\
\hline D3 & 25 & 30.12 \\
\hline S1 & 39 & 46.99 \\
\hline S2 & 6 & 7.23 \\
\hline Sum & 83 & 100 \\
\hline
\end{tabular}

Source: Research results (2020)

Based on a table of 16 descriptive of the frequency of respondents based on education from 83 respondents studied showed that the number of frequency of employee respondents in the South Jakarta Fire Management Agency tribe was the most Many are educated S1 which is as many as 39 people (46.99\%), then the number of employees in the South Jakarta Fire Management Agency tribe educated D3 is as many as 25 people $(30.12 \%)$, the number of employees in the South Jakarta Fire Management Agency tribe educated D3 is as many as 25 people $(30.12 \%)$, the number of employees. The frequency of employees in the South Jakarta Administrative City Fire and Rescue Service Tribe educated high school is as many as 10 people (12.05\%), the number of employees in the Dinas Tribe South Jakarta Fire Management educated S2 is as many as 6 people $(7.23 \%)$. And the number of employees in the South Jakarta Administrative City Fire and Rescue Service Tribe educated as 3 people (3.65\%).

\section{F. Descriptive Statistical Results}

To test the results of the study used spss 23.0 program, including:statistics deskriftif,data quality test (validity and reliability), classical assumption test (normality test), (linearitytest), (multicollinearitytest), and test coefficient of determination (R2), (heteroskedasticity test) as well as hypothesis test (statistical test $\mathrm{t}$ and statistic test $\mathrm{F}$ ).

1. Descriptive Respondent Answers To Employee Competency Variables Rescue (X1), Work Environment (X2), and Service Quality (Y) Descriptive statistical measurement of respondents' answers to variables is done to see minimum values , maximum value, average (mean) and standard deviation variables Of Rescue Employee Competence (X1), Work Environment (X2), and Service Quality (Y) can be presented in the following table:

Table 17. Descriptive Total Competency Variable Score of Employees (X1), Work Environment (X2), and Quality of Service (Y) Descriptive Statistics

\begin{tabular}{|l|c|l|c|c|c|}
\hline & $\mathrm{N}$ & Minimum & Maximum & Mean & Std. Deviation \\
\hline $\begin{array}{l}\text { Employee Competence } \\
\text { (X1) }\end{array}$ & 83 & 100.00 & 850.602 & 833.059 & \\
\hline Work Environment (X2) & 83 & 60.00 & 482.651 & 5552176 & \\
\hline Quality of Service (Y) & 83 & 45.00 & 400.241 & 396932 & \\
\hline Valid N (listwise) & 83 & & & & \\
\hline
\end{tabular}

Based on the table of 17 descriptive statistics above obtained an overview of 83 respondents the description of employee competency variables (X1) shows the minimum value of respondent answers is 70 meaning 3.5 or 4 (agree), the maximum value of 100 means 5 (strongly agree), the average value of respondents' answers is 85.06 meaning 4 (agree) with a standard deviation value of 8.331 ( The standard deviation is very low). For the Working Environment variable (X2) obtained an overview of 83 respondents showed the minimum value of respondent answers is 39 meaning 3(neutral), maximum value of 60 meaning 5 (strongly agree), the average value of respondents' answers is 48,265 meaning 4 (agree) with a standard deviation value of 5,522 (the standard deviation is very low). And for the Service Quality variable (Y) obtained an overview of 83 respondents showed the minimum value of respondent answers is 31 meaning 3 (neutral), the value Maximum of 45 means 5 (strongly agree), the average value of respondents' answers is 40,204 meaning 4 (agree) with a standard deviation value of 3,969 ( The standard deviation is very low).

\section{Conclusion}


The results of the hypothesis (H03) processed by the author state that the competence of employees (X1), the work environment simultaneously has no effect on the quality of service (Y). The result of the hypothesis (Ha3) that competence (X1), and the Work environment (X2) simultaneously affect the quality of service (Y). Ha3. The F-table is calculated by the formula df1=k-1, df2=n-k, $\mathrm{k}$ is the number of competency variables (X1), and the Work environment (X2) to service quality (Y). Based on the Anova table above shows that the F-count value of 26,296> F-table of $3.12(\mathrm{df} 1=3-1=2, \mathrm{df} 2=83-3=80)$ with a significant value of $0.000<\alpha=0.05$. Since F-count 26,296 $>$ F-table 3.12 and significant values of $0.000<\alpha=0.05, \mathrm{H} 0$ is rejected and H1diterima, this proves that the competency variable (X1), and the Work environment (X2) simultaneously have a significant and positive effect on service quality (Y). The results of research according to Purnamasari (2017) which showed that the value of $t$ calculated $(5,621)>t$ table $(1,670)$ then $\mathrm{H} 1$ is accepted means that there is an influence between competence and the work environment affects the quality of service and fire management.

\section{Acknowledgement}

The author would like to thank the South Jakarta Administrative City Fire and Rescue Service, especially to mr. Chief of Fire and Rescue Service of South Jakarta Administrative City because for his support and permission to conduct research in his company this research can run well and smoothly.

\section{References}

[1] P. G. P. D. K. I. J. N. 264 T. O. D. T. K. D. COUNTERMEASURES and K.D. RESCUE, ORGANIZATION AND WORK OF FIRE AND RESCUE SERVICE. 2016.

[2] Mohamad Faisal Amir, Understanding Employee Performance Evaluation: Concepts and Performance Research in the Company. Media Discourse Partners, 2015.

[3] E. Wulandari, "INFLUENCE OF WORK DISCIPLINE AND OCCUPATIONAL HEALTH SAFETY ON EMPLOYEE PERFORMANCE (Case Study on The Tribe of Service On Fire and Rescue Of West Jakarta Administrative City) THESIS," 2018.

[4] A. Risparyanto, "The Influence of Motivation and Competence on the Quality of Librarian Services," Berk. The science of the library. and Inf. , vol. 13, no. 1, p. 1, 2017, doi: 10.22146/beep.26202.

[5] L. Badriyah, "The Influence of Competence and Motivation on the Performance of Employees of The Main Savings and Loan Cooperative (Ksp) of Semarang Branch Work," 2017, [Online]. Available: https://sg.docworkspace.com/d/sIBWb6N1B5KSfgwY.

[6] L. N. Wakhidah and H. Pramusinto, "The Influence of Competence, Employee Discipline, and Physical Work Environment on Quality of Employee Service," vol. 1, no. 3, pp. 265-271, 2021, doi: 10.15294/baej.v1i3.46520.

[7] Sugiyono, Qualitative Quantitative Approach and R\&D Education Research Methods. Bandung: Alfabeta, 2010.

[8] Moeheriono, Competency-Based Performance Measurement. Jakarta: Raja Grafindo Persada, 2014.

[9] Sugiyono, Quantitative Research Method, Qualitative R\&D. Bandung: Alfabeta, 2019. 